\title{
Physical activity level among older adultsover 70 years old and very old adults
}

\author{
Nível de atividade física entre idosos acima de 70 anos \\ e idosos longevos
}

\section{Nivel de actividad física entre ancianos mayores de 70 años $y$ ancianos longevos}

\section{Fátima Ferretti ${ }^{[a]}$, Daiara Macagnan ${ }^{[a]}$, Fernanda Cristieli Canei ${ }^{[a]}$, Márcia Regina da Silva ${ }^{[a]}$, Maria Paula Maia dos Santos [] [b]*}

[a] Universidade Comunitária da Região de Chapecó (UnoChapecó), Chapecó, SC, Brasil

[b] Universidade do Porto (UP), Porto, Portugal

\begin{abstract}
Introduction: Physical activity (PA) is an effective strategy to ensure good health in older adults and mitigate the harmful effects of aging. Objective: To compare PA levels in people aged between 70 and 79 years and very old adults. Method: Quantitative, observational, descriptive cross-sectional study, with 343 individuals aged 70 years or older from a medium-sized municipality in western Santa Catarina state (SC). Data were collected using the MMSE, the Morais' Questionnaire, and the IPAQ-SF. Data were analyzed using the Mann-Whitney U test, $\mathrm{X}^{2}$ and Spearman's correlation. Significance was set at $\mathrm{p}<0.05$. Results: The average physical activity level among 70 to 79 -year-olds was 168.55 ( \pm 146.81$)$ minutes a week and 93.91 $( \pm 122.66)$ in very old adults. IPAQ classification indicated that a higher percentage of very old adults were
\end{abstract}

* FF: PhD, e-mail: ferrettifisio@yahoo.com.br Orcid: 0000-0002-0326-2984 DM: BS, e-mail: daiara@unochapeco.edu.br Orcid: 0000-0001-6155-6932

FSC: BS, e-mail: fernanda_canei@unochapeco.edu.br Orcid: 0000-0002-8356-8579

MRS: Doctoral Student, email:mf@unochapecó.edu.br Orcid: 0000-0002-9930-3102

MPMS: PhD, e-mail: msantos@fade.up.pt Orcid: 0000-0002-2182-9841 
sedentary (79.5\%), while $67.8 \%$ of 70 to 79 -year-olds were categorized as active/very active. There was a statistically significant correlation between physical activity level, number of self-reported chronic diseases and number of medications. Conclusion: Older adults between 70 and 79 years old are more active than very old adults; older women are more active than their male counterparts; the increase in the number of chronic diseases and medications taken lowers physical activity level.

Keywords: Exercise. Aged. Aging.

\section{Resumo}

Introdução: Atividade física (AF) constitui-se numa estratégia eficaz para garantir bons níveis de saúde para os idosos, bem como para reduzir os efeitos deletérios do processo de envelhecimento. Objetivo: Comparar o nível de AF de idosos entre 70 e 79 anos e idosos longevos. Método: Pesquisa quantitativa, observacional, descritiva e transversal com 343 idosos de 70 anos ou mais, de um município de médio porte do extremo oeste de Santa Catarina (SC). Utilizaram-se como instrumentos de coleta de dados o MEEM, o Questionário de Morais e o IPAQ versão curta. A análise de dados foi realizada por meio do teste $U$ de Mann-Whitney, $X^{2}$ e correlação de Spearman. $O$ nível de significância adotado foi de $p<0,05$. Resultados: A média de atividade física de idosos entre 70 e 79 anos foi de 168,55 ( $\pm 146,81$ ) minutos semanais; nos idosos longevos, foi de 93,91 $( \pm 122,66)$. Em relação à classificação do IPAQ, constatou-se que há um percentual maior de sedentários na população longeva (79,5\%); na classificação ativo/muito ativo, evidenciou-se maior frequência na população com idade entre $70 e$ 79 anos (67,8\%). Houve correlação estatisticamente significativa entre o volume de atividade física e o número de doenças crônicas autorrelatadas e o número de medicamentos. Conclusão: Idosos entre 70 e 79 anos são mais ativos do que os longevos; as mulheres idosas são fisicamente mais ativas do que os homens; o volume de atividade física diminui com o aumento do número de doenças crônicas, bem como de medicamentos.

Palavras-chave: Exercício. Idoso. Envelhecimento.

\section{Resumen}

Introducción: La actividad física (AF) se constituye en una estrategia eficaz para garantizar buenos niveles de salud a los ancianos, así como para reducir los efectos dañinos del proceso de envejecimiento. Objetivo: Comparar el nivel de AF de ancianos entre 70 y 79 años y ancianos longevos. Método: Investigación cuantitativa, observacional, descriptiva y transversal, con 343 ancianos de 70 años o más, de un municipio de mediano porte del extremo oeste del estado de Santa Catarina (SC). Se utilizaron como instrumentos de recolección de datos el MEEM, el Cuestionario de Morales y el IPAQ versión corta. El análisis de datos fue realizado por medio de la prueba U de Mann-Whitney, $X^{2}$ y correlación de Spearman. El nivel de significación fue de $p<0,05$. Resultados: El promedio de actividad física de ancianos entre 70 y 79 años fue de $168,55( \pm 146,81)$ minutos semanales; en los ancianos longevos, fue de 93,91 ( $\pm 122,66)$. Con relación a la clasificación del IPAQ, se constató que hay un porcentaje mayor de sedentarios en la población longeva (79,5\%); la clasificación como activo/muy activo se evidenció con mayor frecuencia en la población con edad entre 70 y 79 años $(67,8 \%)$. Se observó una correlación estadísticamente significativa entre el volumen de actividad física y el número de enfermedades crónicas autorrelatadas y la cantidad de medicamentos. Conclusión: Los ancianos entre 70 y 79 años son los más activos que los longevos; las mujeres mayores son físicamente más activas que los hombres; el volumen de actividad física disminuye con el aumento del número de enfermedades crónicas, así como de medicamentos.

Palabras clave: Ejercicio. Anciano. Envejecimiento. 


\section{Introduction}

Human aging is a continuous process marked by biological, physiological, psychological and functional changes that affect how a certain age group is characterized. Moreover, aging is a global phenomenon resulting from the decline in fertility rates and increased life expectancy [1].

The older population is the fastest-growing segment worldwide, with those classified as very old adults ( 80 years or older) exhibiting the greatest increase in Brazil. Epidemiological data indicate a global population of 6.5 million 70 to 79-year-olds, expected to reach 21.4 million by 2050 , while very old adults number approximately 3 million, with an estimated increase of 13.8 million by 2050 [2]. In order to ensure better quality of life for older adults, policies and initiatives targeting this group have focused on developing activities that promote healthy aging, autonomy and independence.

Research has shown that regular physical activity is an effective strategy to ensure good health for older people [3, 4]. Powers and Howley [5] define physical activity (PA) as any muscle and/or body movement produced by muscle contraction that results in higher energy expenditure than resting levels. PA mitigates the harmful effects of aging and improves quality of life, independence, functional capacity and autonomy of individuals [6, 7]. Other studies have shown that individuals of more advanced age have lower activity levels, putting them at risk for chronic noncommunicable diseases $[8,9]$.

Bueno et al. [10] studied 568 older adults and found that $15 \%$ of 70 to 79 year-olds and $2 \%$ of those aged 80 years or more were active, which is worrisome given that staying active is a health protective factor.

Studies that address physical activity in different age groups are important tools in devising public policies and initiatives that promote healthy aging and a health system that meets the needs of the older population; however few studies describe PA levels in very old adults. Considering the above, this study aims to compare physical activity levels in 70 to 79 -yearolds and very old adults from a community in Santa Catarina state (SC), Brazil.

\section{Method}

This quantitative, observational, descriptive cross-sectional study, was approved by the Research
Ethics Committee of a Community University in Santa Catarina (protocol no. 2.047.037/2017).

The population consisted of older individuals aged 70 years or older from a municipality in Santa Catarina, Brazil. Sample size was calculated based on the older population in this age range, which consisted of 5,485 subjects, with a $95 \%$ confidence interval and 5\% sampling error, totaling 360 participants aged $\geq 70$ years.

Inclusion criteria were age greater than or equal to 70 years, reside within the urban perimeter of Chapecó (SC) and exhibit no cognitive impairment according to the Mini Mental-State Examination (MMSE) $[11,12]$. Exclusion criteria were subjects absent from home on two separate visits by researchers, who resided in long-term care facilities (LTCFs), and those who were bedridden, or wheelchair bound.

Nineteen subjects were excluded: three for not achieving the minimum score on the MMSE, eight who were bedridden, one wheelchair bound and seven who declined to take part. Thus, the final sample consisted of 343 older adults, corresponding to $95 \%$ of the estimated sample.

Data were collected using the MMSE, which contains questions on orientation, immediate and delayed recall, attention, language, and visual and spatial reconstruction. The General Information on the Older people questionnaire (Questionário de Dados Gerais de Idosos), adapted from Morais [13], was also applied, with questions regarding living conditions and health of the older population.

Physical activity was assessed using the short form of the International Physical Activity Questionnaire (IPAQ-SF), which contains eight questions and estimates the time spent on PA over a "normal" week, quantified by at least 10 minutes of continuous PA in either locomotion, occupational, recreational or leisure activities, at moderate to vigorous intensity [14]. The classification proposed by Caspersen et al. [15] was used for analysis purposes, divided into three categories:

a) sedentary: any subject who reported not engaging in $\mathrm{PA}$;

b) insufficiently active: those who performed up to 150 minutes of PA a week;

c) active: more than 150 minutes of PA a week.

The population was identified based on data from the Brazilian Institute of Geography and Statistics (IBGE), which divides the city in 
western SC into 38 census tracts, 10 of which were randomly selected.

Data were collected from May to October 2017. First, older individuals of the target age were visited at home and advised on the study objective and procedures. Those who agreed to participate signed a written informed consent and the data collection instruments were then applied by a researcher who received 12 hours of training: four hours aimed at studying the instruments, four to conduct the pilot test, and another four for score analysis and questions.

The MMSE was conducted beforehand to include or exclude the subject from the study. Next, the General Information on the Older people Questionnaire [13] and IPAQ-SF were applied to older individuals who obtained the minimum score of 17 points on the MMSE for those with less than four years of schooling and 24 points for more than four years $[11,12]$.

Data were analyzed using SPSS software, version 20.0. Descriptive statistics were obtained for the variables studied, followed by the KolmogorovSmirnov test to assess the normality of the variables physical activity level (PAL), number of chronic diseases, number of medications, number of falls and pain intensity. Mean PAL scores were compared by age range and between sexes using the MannWhitney $U$ test. The strength of the correlation between weekly PA and number of diseases, number of falls and pain intensity was evaluated by Spearman's correlation. The chi-squared test was applied to analyze PAL by age range and sex. Statistical significance was set at $\mathrm{p}<0.05$.

\section{Results}

Of the 343 older participants, 164 (47.8\%) were 70 to 79 years old and $179(52.2 \%)$ very old, with 216 (63\%) women and 127 (37\%) men. The occurrence of falls was more pronounced in 70 to 79-year-olds (32.9\%) and comparison of the mean numbers of selfreported diseases, medications and falls indicated no statistical intergroup differences ( $p>0.05$ ) (Table 1$)$.

Table 2 shows the time in hours spent on physical activity in a week, with very old adults spending less time on exercise and a statistically significant difference between age groups $(\mathrm{p}=0.001)$.
Table 1 - Profile of the older participants, Chapecó, SC, 2017

\begin{tabular}{|c|c|c|c|}
\hline Variable (n/\%) & $\begin{array}{c}70-79 \\
\text { years } \\
n=164\end{array}$ & $\begin{array}{c}\geq 80 \\
\text { years } \\
n=179\end{array}$ & $\begin{array}{c}\text { Total } \\
\mathrm{n}=343\end{array}$ \\
\hline Men $(n / \%)$ & $58(35.4)$ & $69(38.5)$ & $\begin{array}{c}127 \\
(37.0)\end{array}$ \\
\hline Women $(n / \%)$ & $\begin{array}{c}106 \\
(64.6)\end{array}$ & $110(61.5)$ & $\begin{array}{c}216 \\
(63.0)\end{array}$ \\
\hline Chronic diseases (n/\%) & $\begin{array}{c}151 \\
(92.1)\end{array}$ & $163(91.1)$ & $\begin{array}{c}314 \\
(91.5)\end{array}$ \\
\hline Use of medication (n/\%) & $\begin{array}{c}153 \\
(93.3)\end{array}$ & $166(92.7)$ & $\begin{array}{c}319 \\
(93.0)\end{array}$ \\
\hline Occurrence of falls (n/\%) & $54(32.9)$ & $52(29.1)$ & $\begin{array}{c}106 \\
(30.9)\end{array}$ \\
\hline Chronic pain (n/\%) & $\begin{array}{c}101 \\
(61.6)\end{array}$ & $108(60.3)$ & $\begin{array}{c}209 \\
(60.9)\end{array}$ \\
\hline $\begin{array}{l}\text { No. of chronic diseases } \\
\mathrm{SR}^{\star}(\mathrm{m} / \pm \mathrm{sd})\end{array}$ & $\begin{array}{c}1.93 \\
(1.14)\end{array}$ & $1.98(1.22)$ & $\begin{array}{c}1.96 \\
(1.18)\end{array}$ \\
\hline $\begin{array}{l}\text { No. of medications } \\
(\mathrm{m} / \pm \mathrm{sd})\end{array}$ & $\begin{array}{c}3.06 \\
(1.99)\end{array}$ & $3.30(2.06)$ & $\begin{array}{c}3.18 \\
(2.03)\end{array}$ \\
\hline No. of falls $(m / \pm s d)$ & $\begin{array}{c}0.82 \\
(1.78)\end{array}$ & $0.52(1.15)$ & $\begin{array}{c}0.66 \\
(1.49)\end{array}$ \\
\hline
\end{tabular}

Note: table compiled by the authors (2018). SR: self-reported.

Table 2 - Classification of Physical Activity Level - IPAQ by age group and sex, Chapecó, SC, 2017

\begin{tabular}{|c|c|c|c|c|c|}
\hline \multicolumn{2}{|c|}{$\begin{array}{l}\text { IPAQ } \\
\text { Classification }\end{array}$} & $\begin{array}{c}\text { 70-79 } \\
\text { years } \\
\text { n (\%) }\end{array}$ & $\begin{array}{c}\geq 80 \text { years } \\
n(\%)\end{array}$ & $X^{2}$ & p \\
\hline \multirow[t]{4}{*}{ Overall } & SED & $15(20.5)$ & 58 (79.5) & 42.027 & $0.0001^{\dagger}$ \\
\hline & IA & $69(45.1)$ & $84(54.9)$ & & \\
\hline & $A$ & $80(68.4)$ & 37 (31.6) & & \\
\hline & Total & $164(100)$ & $179(100)$ & & \\
\hline \multirow[t]{4}{*}{ Men } & SED & $5(8.6)$ & $16(23.2)$ & 11.280 & $0.004^{*}$ \\
\hline & $\mathrm{IA}$ & 19 (32.8) & 32 (46.4) & & \\
\hline & $A$ & $34(58.6)$ & $21(30.4)$ & & \\
\hline & Total & 58 (100) & $69(100)$ & & \\
\hline \multirow[t]{4}{*}{ Women } & SED & $10(9.4)$ & 42 (38.2) & 34.185 & $0.0001^{\dagger}$ \\
\hline & IA & 50 (47.2) & 52 (47.3) & & \\
\hline & $A$ & 46 (43.4) & $16(14.5)$ & & \\
\hline & Total & $106(100)$ & $110(100)$ & & \\
\hline
\end{tabular}

Note: table compiled by the authors (2018). IPAQ: International Physical Activity Questionnaire; SED: Sedentary; IA: insufficiently active; A: Active; $X^{2}$ : Chi-squared test; *: Statistical significance-p $<0.05$; ${ }^{+}$. Statistical significance-p $<0.0001$.

Table 3 shows the average number of hours spent on physical activity per week. The results demonstrate a statistically significant difference, indicating that very old adults engage in less physical activity in a week $(p=0.001)$. 
Table 3 - Comparison of the average number of hours per week spent on physical activity by age group, Chapecó, SC, 2017

\begin{tabular}{|c|c|c|c|}
\hline Variable & $\begin{array}{c}\text { 70-79 years } \\
\text { m ( } \pm s d)\end{array}$ & $\begin{array}{c}\geq 80 \text { years } \\
m( \pm s d)\end{array}$ & $p$ \\
\hline FSIPAQ & 168.55 (146.81) & 93.91 (122.66) & $0.001^{*}$ \\
\hline FSIPAQ_WOM & $160.41(160.61)$ & 79.92 (122.93) & $0.0001^{\dagger}$ \\
\hline FSIPAQ_MEN & 183.45 (117.35) & $116.20(119.74)$ & $0.001^{*}$ \\
\hline
\end{tabular}

Note: table compiled by the authors (2018). FSIPAQ: Final Score on the International Physical Activity Questionnaire; FSIPAQ_WOM: Final Score on the International Physical Activity Questionnaire among women; FSIPAQ_MEN: Final Score on the International Physical Activity Questionnaire among men; $p$ : Mann-Whitney U test; *: Statistical significance-p $<0.05 ;{ }^{\dagger}$ : Statistical significance- $p<0.0001$.

Analysis of the association between physical activity level (PAL) and number of chronic diseases indicated a statistically significant negative correlation $(\mathrm{r}=-0.124 ; \mathrm{p}=0.022)$. The same was observed between PAL and the number of medications taken $(r=-0.179 ; p=0.001)$, but no correlation with the number of falls ( $\mathrm{r}=-0.103$; $\mathrm{p}=0.057$ ) (Figure 1).
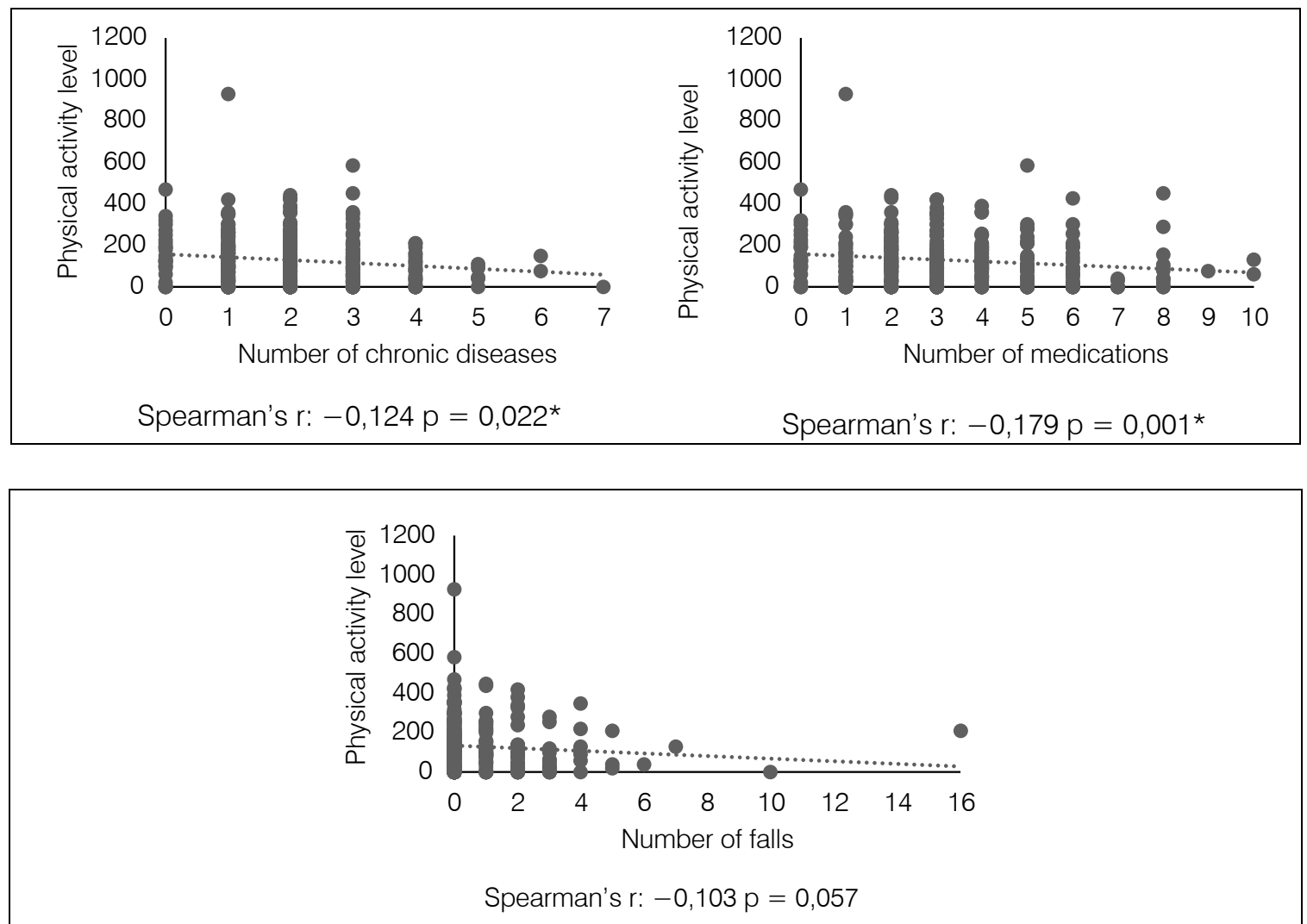

Note: Graph elaborated by the authors (2018). Spearman's r: Spearman's correlation test. $p$ : Spearman's correlation test; *: Statistical significance-p $<0.05$.

Figure 1 - Correlation between physical activity level and the number of chronic diseases, medications taken and falls, Chapecó, SC, 2017.

\section{Discussion}

This study showed that the older the participant, the less time they spent on physical activity $(p<0.001)$, with very old adults exercising for an average of 93.91 minutes $( \pm 122.66)$ a week and 70 to 79 -year-olds 168.55 minutes ( \pm 146.81 ). Also, that PA differed between 70 to 79 -year-old women and those older than 80 years $(\mathrm{p}<0.001)$, and likewise among men $(\mathrm{p}<0.006)$.

These data corroborate Bueno et al. [10], who described the PA profile of the older population from 
a municipality in the state of São Paulo and concluded that the number of physically active older adults declines with advancing age. Krug et al. [16] assessed PA in 343 subjects aged 80 years or more and found a prevalence of $19.5 \%$. Very old adults $(\mathrm{p}=0.011 ; \mathrm{OR}=0.90$; $95 \% \mathrm{CI}=0.83 / 0.98$ ) with worse self-rated health $(\mathrm{p}<0.001 ; \mathrm{OR}=0.33 ; 95 \% \mathrm{CI}=0.18 / 0.60)$ and systemic hypertension ( $\mathrm{p}=0.009 ; \mathrm{OR}=0.47 ; 95 \% \mathrm{CI}=0.27 / 0.83$ ) were less likely to engage in locomotor activity.

A study based on interviews conducted by the 2013 National Health Survey describing involvement in, knowledge of and the reasons why the young old and very old do not participate in public physical activity programs outlines a worrisome scenario. Results indicated that of the 9,679 young old and 1,498 very old participants, $78.9 \%$ of older Brazilians do not engage in exercise, with significant differences between the young $(77.3 \%)$ and very old (89.3\%). Additionally, $81.6 \%$ were not aware of the programs, and among those who were, most (82.6\%) did not take part, citing lack of interest (39\%) as the reason for not participating and walking for preferred activity (58.4\%) [17].

These data indicate a need to improve diffusion of public programs that encourage physical activity among older adults, besides examining and rethinking the communication strategies used to publicize them. It is essential to raise awareness about the importance of PA in any age group and adjust programs to the needs and aspirations of individuals throughout their lives.

Another finding of this study was that 70 to 79-year-old men are more active (58.6\%) than their very old counterparts (30.4\%). Moreover, a higher percentage of the insufficiently active were women from both age ranges, with $47.2 \%$ for 70 to 79 -yearolds and $47.3 \%$ among those aged 80 years or more. Both men and women exhibited a decline in PAL with advanced age, with higher levels among older men in both age groups.

A similar result was shown in a study with 130 older individuals (average age 73.18 years). Regarding the type of activity, men favored walking and vigorous exercise, while women performed more moderate activities [18]. Tribess et al. [19] studied a group of 622 older adults ( 218 men and 406 women) and reported an average of $295.5( \pm 281.8) \mathrm{min} /$ week for moderate to vigorous exercise, with no difference between sexes. When physical activity domains were analyzed separately, there were significant differences in the means, with men spending more time on work, transport and leisure activities and women on household tasks.

A study by Krug et al. [9] with 60 to 85 -yearolds also found a statistically significant difference between the sexes for PAL ( $p=0.04)$, with older men spending more time on work-related activities than their female counterparts. The authors emphasized that what contributes most to helping older adults stay active, regardless of sex, is household chores. These occupied the most time in this age group, who largely performed them at moderate intensity, keeping them active and autonomous in their daily lives.

Exploring the differences between the sexes in predictors of PA in 304 older individuals, Chen et al. [20] reinforced that men engaged in more vigorous activities than women. Factors that negatively affected physical activity in older men were age, number of chronic diseases and depression; and in women the number of chronic diseases and depression.

In this study, $91.5 \%$ of participants had one or more self-reported chronic diseases, and a statistically significant negative correlation ( $\mathrm{r}=-0.124 ; \mathrm{p}=0.022$ ) was observed between PAL and the number of chronic diseases.

Oliveira et al. [21] reported that most over 70-year-olds had at least one disease, which increases with age [22], resulting from continuous loss of body function, which leads to functional impairment and disabilities that reduce physical activity.

Brito et al. [23] also reported an association between functional impairment, number of selfreported diseases and self-rated health, regardless of sex. The authors observed a statistically significant correlation between functional impairment and number of chronic diseases; and between self-rated health and PA, the latter only among men. Older individuals who reported four or more chronic diseases, perceived their health as poor and did not engage in physical activity, exhibited a high prevalence of functional impairment.

A study by Gopinath et al. [24] demonstrated that high PALs increased the likelihood of surviving 10 more years without chronic disease, cognitive or functional impairments. The authors also highlighted the importance of investing in public health initiatives to encourage older people to engage in physical activity. Adopting a healthy lifestyle and diet, engaging in physical activity, managing stress, taking preventive 
measures and fostering social relationships are factors that contribute to longevity [25].

In order to ensure healthy choices that help prevent chronic illnesses and maintain good PALs and functionality, thereby mitigating the harmful effects of aging, public policies aimed at improving older adults' participation and adherence to programs that raise awareness and encourage empowerment needs to be stablished.

Santos et al. [26] assessed 1656 older adults, 68.5 $\%$ of whom were classified as insufficiently active (IA), and found that those with lower schooling levels and income who were IA displayed a greater prevalence of chronic conditions, including pain. Leijon et al. [27] investigated 1358 patients from primary health care facilities in Sweden and observed that chronic pain was the most common reason given by older patients for not adhering to PA. Sawatzky et al. [28] studied older subjects in Canada and reported that those with a larger number of chronic illnesses were less likely to participate in physical activity programs. As such, to guarantee the health of this population it is essential to establish preventive strategies to minimize the risks of developing chronic diseases and encourage PA.

Baert et al. [29] conducted a systematic review to identify barriers and motivators for engaging in PA among those aged 80 years or older and found no studies dedicated solely to this age group, a research gap that needs to be addressed. Regarding general factors, the authors highlighted that since PA programs aim to provide health benefits, they should consider older people's fears of trying something new and ensure proper supervision, acknowledge individual preferences and the need for social support, as well as restrictions in the physical environment. Establishing health education programs to raise awareness about the importance of PA seems to be the most promising means of achieving this goal.

Krug et al. [30] assessed perceived barriers and facilitators for physical activity in 30 very old women and concluded that physical limitations, lack of interest, overprotective family members, inappropriate physical activities, illness, safety concerns, marriage and child care, never having engaged in recreational physical activity, advanced age, and fear of falling were the major barriers. The main facilitators were enjoying PA, socializing, PA benefits, appropriate exercises and having company to exercise.
Health education initiatives should target all age groups, in order to raise awareness about the importance of PA, develop mechanisms to promote adherence and improve strategies that foster a healthy lifestyle and habits, as well as preventive behavior to minimize risk factors for chronic diseases.

Older adults with chronic conditions may become heavily dependent on medication. A recent study demonstrated that individuals with hypertension, diabetes and high cholesterol took on average 4.8 drugs per day, driven not only by their individual health needs, but also the strong marketing influence of the pharmaceutical industry [31].

Of the subjects assessed in this study, 93\% reported taking at least one medication, with use varying from one to ten, and an average of $3.18( \pm 2.03)$. A national survey of 3,000 older adults selected from those registered in the Brazilian Social Welfare Institute assessed factors associated with medication use and found that $83 \%$ took medication, $78.8 \%$ in 60 to 69 -year-olds and $87.3 \%$ in those aged 70 and over ( $p<0.05)$, with the latter using on average 4.4 drugs and the former 3.3. Being 70 years old or more, female, poor self-rated health, interruption of routine daily activities, more than six doctor's appointments in the previous year, having private health insurance and reporting 4 or more illnesses were associated with medication use [32].

Medication intake increases as the population ages. Although the average number of medications in those $\geq 80$ years old $(3.30 \pm 2.06)$ was lower than in younger participants $(3.06 \pm 1.99)$, there was no statistically significant difference between the age groups.

Oliveira et al. [33] conducted an integrative review of medication use by older people in basic health care and examined 76 articles published primarily in English and produced in the USA, England and Brazil. The authors identified a trend of drug use in this group, particularly psychotropic medications and polypharmacy, highlighting the need to establish strategies for preventing adverse events and adopting technologies that facilitate medication control for older adults.

Another significant finding of this study was the weak negative correlation between PAL and the number of medications taken $(r=-0.179 ; p=0.001)$, which suggests that a rise in PAL reduces medication use in older people. This corroborates Lago et al. [34], who reported that low PAL resulted in greater predisposition to illness and high drug intake. 
Among chronic conditions, falls and different types of fractures are also cited. Gasparotto et al. [35] studied 256 older individuals and concluded that the greater their mobility, the less likely they were to fall, which was directly related to higher levels of physical activity. However, there was no significant correlation between PAL and number of falls in this study.

A systematic review analyzing the most recent scientific evidence regarding the effect of physical exercise on preventing falls in community-dwelling older adults concluded that PA is effective at preventing falls, and exercise programs combining balance training with 3 or more hours of exercise a week produced the best results, suggesting moderate to intense PA for long-term fall prevention [36].

Our study reinforces the literature about highlighting the importance of implementing strategies to ensure older adults stay active, regardless of age and type of activity. This effective, low-cost nonpharmacological approach could contribute to minimizing different chronic conditions in older people and a longer life with greater independence, autonomy and quality.

\section{Conclusion}

The average level of physical activity among 70 to 79-year-olds was $68.55( \pm 146.81)$ minutes a week, higher than very old adults $(93.91 \pm 122.66)$, indicating that the former were more active and that the older the subject, the less time they spent on exercise. Additionally, older men were more physically active than women. A negative correlation was observed between PA and the number of chronic illnesses and medication intake.

Given the increased life expectancy of the Brazilian population, with a larger number of people aged 70 years and over, the results indicate the need to improve public strategies that encourage regular physical activity as a low-cost nonpharmacological approach to ensure good health. Helping older adults stay active and preserving their functional independence and autonomy are major challenges for the Brazilian public health system. In this respect, it is vital to provide a continuous and integrated model of care for older people that prioritizes programs and initiatives aimed at minimizing functional losses while ensuring this population stays active and retains its independence.
A limitation of this study were the self-reported measures. However, the description of PA levels in older adults is a strong point because it establishes a relationship with other health and autonomy indicators in a representative sample.

\section{References}

1. Sá CA, Ferretti F, Busato MA. Ensaios contemporâneos em saúde: ambiente e envelhecimento numa perspectiva interdisciplinar. Chapecó: Argos; 2012.

2. Instituto Brasileiro de Geografia e Estatística. Projeção da população do Brasil por sexo e idade: 2000-2060. Rio de Janeiro: IBGE; 2013

3. Freire RSL, Lélis FLO, Fonseca Filho JA, Nepomuceno MO, Silveira MF. Prática regular de atividade física: estudo de base populacional no Norte de Minas Gerais, Brasil. Rev Bras Med Esporte. 2014;20(5):345-9.

4. Souza IL, Francisco PMSB, Lima MG, Barros MBA. Nível de inatividade física em diferentes domínios e fatores associados em adultos: inquérito de saúde no município de Campinas (ISACamp, 2008/2009), São Paulo, Brasil. Epidemiol Serv Saude. 2014;23(4):623-34.

5. Powers SK, Howley ET. Fisiologia do exercício: teoria e aplicação ao condicionamento e ao desempenho. 8th ed. Barueri: Manole; 2014.

6. Sá PHVO, Cury GC, Ribeiro LCC. Atividade física de idosos e a promoção da saúde nas unidades básicas. Trab Educ Saude. 2016;14(2):545-58.

7. Rodrigues WKM, Rocha SV, Vasconcelos LRC, Diniz KO. Atividade física e incapacidade funcional em idosos da zona rural de um município do Nordeste do Brasil. Rev Bras Promoç Saude. 2015;28(1):126-32.

8. Pegorari MS, Dias FA, Santos NMF, Tavares DMS. Prática de atividade física no lazer entre idosos de área rural: condições de saúde e qualidade de vida. Rev Educ Fís. 2015;26(2):233-41.

9. Krug RR, Conceição JCR, Garcia GS, Streit IA, Mazo GZ. Idosos praticantes de atividades físicas: relação entre gênero e idade. Biomotriz. 2011;(5):1-16. 
10. Bueno DR, Marucci MFN, Gomes, IC, Duarte YAO, Lebrão ML. Nível de atividade física por acelerometria, em idosos do município de São Paulo: estudo SABE. Rev Bras Med Esporte. 2016;22(2):108-12.

11. Crum RM, Anthony JC, Bassett SS, Folstein MF. Population-based norms for the Mini-Mental State Examination by age and educational level. J Am Med Assoc. 1993;269(18):2386-91.

12. Pereira N, Kochhann R, Zimmermann N, Fonseca RP. Mini-Exame do Estado Mental na avaliação neuropsicológica pós-TCE: aplicabilidades. Diaphora. 2013;12(2):58-63.

13. Morais EP, Rodrigues RAP, Gerhardt TE. Os idosos mais velhos no meio rural: realidade de vida e saúde de uma população do interior gaúcho. Texto Contexto Enferm. 2008;17(2):374-83.

14. Benedetti TRB, Antunes PC, Rodriguez-Añez CR, Mazo GZ, Petroski EL. Reprodutibilidade e validade do Questionário Internacional de Atividade Física (IPAQ) em homens idosos. Rev Bras Med Esporte. 2007;13(1):11-6.

15. Caspersen C, Powell K, Christenson G. Physical activity, exercise, and physical fitness: definitions and distinctions for health-related research. Public Health Rep. 1985;100(2):126-31.

16. Krug RR, Lopes MA, Balbé GP, Marchesan M, Mazo GZ. Prevalence of commuting physical activity and associated factors in long-lived older adults. Rev Bras Cineantropom Desempenho Hum. 2016;18(5):520-9.

17. Printes CB, Brauner FO, Rocha JP, Oliveira G, Neris J, Rauber B, et al. Prática de exercício físico ou esporte dos idosos jovens e longevos. Pajar. 2016;4(2):47-53.

18. Castañeda FJR, Aznar CT, Baquero CM. Medición de la actividad física em personas mayores de 65 años mediante el IPAQ-E: validez de contenido, fiabilidade y factores asociados. Rev Esp Salud Publica. 2017;91(1):1-12.

19. Tribess S, Virtuoso JS Jr, Oliveira RJ. Atividade física como preditor da ausência de fragilidade em idosos. Rev Assoc Med Bras. 2012;58(3):341-7.
20. Chen YM, Li YP, Yen ML. Gender differences in the predictors of physical activity among assisted living residents. J Nurs Scholarsh. 2015;47(3):211-8.

21. Oliviera IA, Kronbauer GA, Binotto MA. Doenças e nível de atividade física em idosos. RBCEH. 2012;9(2):263-73.

22. Virtuoso JF, Streit IA, Krug RR, Mazo GZ, Fatores associados à longevidade em idosos praticantes de exercícios físicos: um estudo descritivo. Estud Interdiscipl Envelhec. 2015; 20(1):235-48.

23. Brito KQD, Menezes TN, Olinda RA. Incapacidade funcional: condições de saúde e prática de atividade física em idosos. Rev Bras Enferm. 2016;69(5):773-80.

24. Gopinath B, Kifley A, Flood VM, Mitchell P. Physical Activity as a Determinant of Successful Aging over Ten Years. Sci Rep. 2018;8:1-5.

25. 25. Souza MAH, Porto EF, Souza EL, Silva KI. Profile of lifestyle of older elderly persons. Rev Bras Geriatr Gerontol. 2016;19(5):819-26.

26. Santos FAA, Souza JB, Antes DL, Orsi E. Prevalência de dor crônica e sua associação com a situação sociodemográfica e atividade física no lazer em idosos de Florianópolis, Santa Catarina: estudo de base populacional. Rev Bras Epidemiol. 2015;18(1):234-47.

27. Leijon ME, Faskunger J, Bendtsen P, Festin K, Nilsen P. Who is not adhering to physical activity referrals, and why? Scand J Prim Health Care. 2011;29(4):234-40.

28. Sawatzky R, Liu-Ambrose T, Miller WC, Marra CA. Physical activity as a mediator of the impact of chronic conditions on quality of life in older adults. Health Qual Life Outcomes. 2007;5(68):1-11.

29. Baert V, Gorus E, Mets T, Geerts C, Bautmans I. Motivators and barriers for physical activity in the oldest old: A systematic review. Ageing Res Rev. 2011;10(14):464-74.

30. Krug RR, Lopes MA, Mazo GZ. Barreiras e facilitadores para a prática da atividade física de longevas inativas fisicamente. Rev Bras Med Esporte. 2015;21(1):57-64. 
31. Hunt LM, Kreiner M, Brody $\mathrm{H}$. The changing face of chronic illness management in primary care: a qualitative study of underlying influences and unintended outcomes. Ann Fam Med. 2012;10(5):452-60.

32. Silva AL, Ribeiro AQ, Klein $\mathrm{CH}$, Acurcio FA. Utilização de medicamentos por idosos brasileiros, de acordo com a faixa etária: um inquérito postal. Cad. Saude Publica. 2012;28(6): 1033-45.

33. Oliveira LPBA, Santos SMA. An integrative review of drug utilization by the elderly in primary health care. Rev Esc Enferm USP. 2016;50(1):1-13.

34. Lago C, Morais GL, Guarda FRB, Simões PW, Farias JM. Relação do nível de atividade física habitual e consumo de medicamentos em usuários do Sistema Único de Saúde. Rev Bras Ativ Fís Saude. 2016;21(4):371-8.
35. Gasparotto LPR, Falsarella GR, Coimbra AMV. As quedas no cenário da velhice: conceitos básicos e atualidades da pesquisa em saúde. Rev Bras Geriatr Gerontol. 2014;17(1):201-9.

36. Bento JR, Souza ND. Exercício físico na prevenção de quedas do idoso da comunidade: Revisão baseada na evidência. Rev Bras Med Fam Comunidade. 2017;12(39):1-11.

Received in: $12 / 11 / 2018$

Recebido em: $11 / 12 / 2018$

Recibido en $11 / 12 / 2018$

Approved in: 01/07/2020

Aprovado: 07/01/2020

Aprobado en: 07/01/2020 